\title{
Investigation of influence of additives on properties of multi-molecular organic solutions used for permeation grouting
}

\author{
Rimantas Mackevičius ${ }^{1}$, Danute Sližyte் ${ }^{2}$, Tatyana $Z_{\text {hilkina }}^{3}$, Vadim Turchin ${ }^{4}$ \\ ${ }^{1,2}$ Department of Reinforced Concrete Structures and Geotechnics, Faculty of Civil Engineering, \\ Vilnius Gediminas Technical University, Vilnius, Lithuania \\ ${ }^{3}$ Institute of Civil Engineering and Architecture, \\ Moscow State University of Civil Engineering, Moscow, Russia \\ ${ }^{4}$ Civil Engineering Company LLC Stroy-Expert, Izhevsk, Russia \\ E-mail: 'rimantas.mackevicius@vgtu.lt (correspondingauthor)
}

\begin{abstract}
Permeation grouting for stabilization of dispersive sandy and gravely soils is in use from beginning of 19th century and has high importance for various underpinning, tunneling, and structural strengthening works. As materials for permeation grouting are applied not only cement mortar or silica gel in many compositions but multi-molecular organic solutions too. From multi-molecular organic solutions for permeation grouting are in use various synthetic resins such as acrylic, urea-formaldehyde, or other polymer resins. Urea-formaldehyde resin has right physical and mechanical properties for applying in soil stabilization but additives can change these properties. For example, additives can increase density, pH-rate, and gel-formation time of urea-formaldehyde resin. Additives can decrease viscosity of solutions based on urea-formaldehyde resin. Additives can improve environmental aspects of use of multi-molecular organic solutions for grouting of sandy soils. Long-time investigations of influence of additives on properties of multi-molecular organic solutions used for soil stabilization give good results for optimization of composition of materials for grouting.
\end{abstract}

Keywords: grouting, soil stabilization, laboratory testing, geotechnics, urea-formaldehyde resin.

\section{Introduction}

The essence of ground injection or grouting is artificial soil stabilization, i.e. altering the ground characteristics effecting disperse soil by adhesive materials and turning it into an artificial rock that is solid and waterproof. Permeation grouting is the oldest and remains the most common type of grouting used (Henn, 1996). Grouting is widely used as a ground improvement technique because of easy execution with small equipment (Nasu, 2000).

Permeation grouting for stabilization of dispersive sandy and gravely soils is in use from beginning of 19th century. Stabilizing material was first time injected into soil in France as early as during the reign of Napoleon, in 1802. Attempting to isolate the watery gravel interlayer, which prevented from smooth reconstruction of sluice at port of Dieppe, engineer Charles Berigny invented the method of soil injection and reinforced the gravel with pozzolanic grout. He was the first to use the term procédé d'injection (translated from French into English, procedure of injection). In 1810, Berigny used the injection method second time for stabilizing the supporting base of a bridge over the river Seine in Sèvres, near Paris (Cambefort, 1964).

Soil reinforcement by injections is a one rational way to improve the grounds under buildings. A solid, waterproof artificial rock is formed when injecting low viscosity (similar to that of water) solution with low pressure (up to 1.0 MPa), that forms crystal connections between disperse particles while hardening, into the soil (Bell, 2013). That resembles natural process when free-flowing sand can turn into sandstone when it gets cemented by natural cements.

Stabilizing solution injection into soil pores can be compared to injection of medicines into human body. In both cases, the structure - soil or human body tissues - cannot be destroyed. The solution is being injected with as low pressure as possible, and when it fills the pores, it does its work: it cures a patient or reinforces the soil.

Permeation grouting is the process of injecting low-viscosity fluids that set into voids of dispersive soil like sand and gravel or in open cracks of cracked rock (Houlsby, 1990). Two purposes of grouting are for first to reduce the flow of seepage through a ground and for second to strengthen a ground. There is a difference between grouting of voids in sand or gravel and grouting of cracks in rock. Cement grout is only useful in coarse gravel free of finer material (Bruce, 1994). The cement grout can only travel in the larger voids. In the finer-sized materials such as sand or silt, voids are too small to accept cement grout. 
For finer-sized materials in 1887 , engineer Jeziorsky patented a water permeable disperse rock reinforcement method used in mining works, when sodium silicate (liquid glass or water-glass) and subsequently calcium chloride solutions are injected into coarse (rough) or medium coarse sand soil (Warner, 2004). Interacting in soil pores, these solutions end up in silicic acid gel, which works on making the sand solid and waterproof. Unfortunately, the chemicals reacted soon after mixing, requiring very rapid injection, and, all too often, hardened in the pump and delivery system, which restricted their application. To overcome the problem of early hardening, Joosten, a Dutch mining engineer, developed a two-shot sodium silicate-based system, patented in 1925.

In 1909, French engineers Lemaire and Dumaunt patented a method, where sodium silicate is mixed with acid, and this mixture is injected into soil where it turns into weak, waterproof gel. Geyrard, Rodio and others further developed this method (Kutzner, 1996).

Volumes of injected soil greatly increased in 1920's when metro tunnels were intensively built in world's big cities (Paris, London, Berlin, Hamburg), therefore, grounds of adjacent buildings, sometimes the tunnel arches, too, needed to be reinforced. Non-organic and organic multimolecular compound based solutions were started to use along with cement suspension, as the latter was suitable for injections into gravel only, because it could not penetrate into soils with smaller particles.

Chemical grouting makes use of any grout that is a pure solution with no particles in suspension. Because it does not have any solids in suspension, it can penetrate finer soils. The groutability of chemical grouts depends on their viscosity (Briaud, 2013). Chemical grout can be used in soils as fine as coarse silt.

Sodium silicate based solutions are the most commonly used non-organic chemical substances for soil injections, and some organic polymers as synthetic resins (urea formaldehyde, acrylic, urethane, furane, resorcin formaldehyde) are successfully used for grouting too (Nonveiller, 2013). Polymeric resins allow reinforcing sand of various granulometric and mineral consistence (even the fine-grain sand with filtration rate of a $1 \mathrm{~m} /$ day), make it stable and waterproof (Karol, 2003). Organic polymeric solutions are successfully used not only for building ground stabilization, but also for bridge ground strengthening, tunnel arches stabilization, cracked rock reinforcement (Gallavresi, 1992).

In 1940's, along with the first developing trend of ground reinforcement by injections based on the use of multimolecular non-organic compounds (i.e. use of polymers with molecules having non-organic main chains and having no organic origin radicals), emerged the second trend. It was based on the use of organic polymers (synthetic resins). Realia of the Second World War also influenced application of these compounds for soil stabilization. The first time organic polymers have been used for soil reinforcement when the army of USA and England attempted to crash the German defence on the coast of Normandy (Winterkorn, 1955).

The new trend was being developed very keenly in USA (Welsh, 1996), Japan (Choi \& Yanagisawa, 1996) and Soviet Union (Sokolovich, 1980) in the postwar period. However, in Western Europe, it was viewed more cautiously. In the wake of the Second World War, when synthetic resins were started to use for ground stabilization, the improved physical and mechanical soil characteristics (waterproof, high compression strength, durability) were greatly applauded and for at least some time, there were no concerns about the polymeric solutions impact on environment.

Decrease of reliability level of reinforced concrete structures in soil is dependent from influence of acceptable defects (Belentsov \& Smirnova, 2018). While in Lithuania the permeation grouting method was rarely used (only once geotechnical company Geostatyba applied Swedish TACSS formula chemical solution for soil stabilization in Elektrenai), globally it is popular (e.g. in sealing the arch of the English Channel tunnel: water flow to the tunnel through cracked grey limestone in which the tunnel was drilled under the strait bottom, was eliminated).

In the last few years, ground treatment has made significant progress (Welsh \& Burke, 2000). Innovative products include environmentally friendly grout mixes, which are capable of permeating fine sand even with some silt content (Granata, Vanni, \& Mauro, 2015).

Today in soil stabilization with polymer resins one of the biggest problems is optimization of composition of polymer solutions applicate for permeation grouting. In our work, we investigate grout on base of urea-formaldehyde resins, analyse influence of different compositions and different hardeners on compressive strength and environmental characteristics of grout and grouted sandy soil in laboratory tests.

\section{Permeation grouting with urea-formaldehyde resins and environmental aspects of this activity}

Artificial resins are solutions of multi-molecular organic oligomers with a small molecular mass. When hardening, they turn into insoluble and infusible polymers with three-dimensional structure. Out of many synthetic compositions for permeation grouting, urea-formaldehyde, acrylic, polyurethane, and furan resins proved to be the most applicable.

Urea-formaldehyde resins compose when urea $\mathrm{CO}\left(\mathrm{NH}_{2}\right)_{2}$ is polycondensed with formaldehyde $\mathrm{CH}_{2} \mathrm{O}$. They display thermo-reactionary characteristics: in high temperature, and in some conditions, in room temperature, from them flowing state, they turn into viscous-flowing, later - into hard, insoluble, and irreversible state.

English chemist William Carruthers offered grouping polymers into polycondensed and polymerized. According him, polycondensed polymers are those formed from poly-functional monomer, and products with small molecular mass (for example, water) are separated. Polymerized are those that form from monomers, but do not separate any other product. Urea-formaldehyde resin is a polycondensed polymer. 
The first to investigate the urea-formaldehyde resin for its application in soil stabilization was American engineer Lawton. In 1947, using this resin, he grouted aqueous sand in an oil well. He applied ammonium chloride $\mathrm{NH}_{4} \mathrm{Cl}$ as a resin hardener.

In next years, soils were grouted with urea-formaldehyde resins in many different countries (for example, in USA and in USSR). It surely stabilized sandy soils. It would provide high compression strength (of up to $10 \mathrm{MPa}$ ), water impermeability and durability of grouted soil. Solutions of hydrochloric acid $\mathrm{HCl}$ ( 3 or 5 percent), organic oxalic acid $\mathrm{H}_{2} \mathrm{C}_{2} \mathrm{O}_{4}(6 \%)$, and ferric chloride $\mathrm{FeCl}_{3}(18 \%)$ are used as hardeners.

The main disadvantage of urea-formaldehyde resins that limited their more often application in underground structures for a long time was high quantities of free formaldehyde - toxic material irritating human nose and eyes even at low concentrations - in the resin solution and stabilized soil.

The content of free formaldehyde in urea-formaldehyde resin used for chemical stabilization of soils attains $2 \%$. Its liberation increases sharply in the hardening process of the resins, however, since a significant portion of the water contained in the resin, and liberated during its condensation, goes over into the bonded state where it cannot absorb and retain the free formaldehyde that is liberated. The latter therefore passes from the stabilized sandy soil to the environment; this is also promoted by the low boiling point of formaldehyde $\left(-19.2^{\circ} \mathrm{C}\right)$.

Owing to their accessibility and low price, urea-formaldehyde resins have come into frequent consumption in geotechnical engineering for sandy soil stabilization.

It is known that free formaldehyde dissolves readily in water, forming a saturated formalin solution with a formaldehyde content of up to $37 \%$ at normal temperature, and mixes readily with air in any proportion. The density of gaseous formaldehyde is close to that of air; this permits the free circulation of the formaldehyde that goes off into the atmosphere.

The maximum allowable concentration (MAC) of formaldehyde in the air should not exceed $0.5 \mathrm{mg} / \mathrm{m}^{3}$ for industrial and $0.012 \mathrm{mg} / \mathrm{m}^{3}$ for residential air space. The MAC of formaldehyde should not be higher than $0.005 \mathrm{mg} / \mathrm{litre}$ in agricultural and drinking water and recreation water supply.

Chemical products such as urea-formaldehyde resins, silicates, polyurethanes or others can be used in grouting work subject to compliance with environmental legislation. Environmental impact, particularly the toxicity of the grout and the grout components and their effect on the ground water and drinking water should be considered before grouting.

Industry normally produces urea-formaldehyde resins in the form of glues, which are products of the initial stage of condensation. These resins are readily soluble in water and have negligible viscosity; this makes it possible to use them as injection grouts to stabilize sandy and gravelly soils. The fact that they harden at normal temperature when inexpensive ion hardeners of the acid or acid-salt type are introduced in them is a major asset of these resins.

\section{Laboratory testing of urea-formaldehyde resin solutions}

Such properties of urea-formaldehyde resin solutions have been investigated in laboratory from authors of this paper: density, viscosity, $\mathrm{pH}$ (alkalinity level), gel time, and evaporation of formaldehyde from solution into air.

Density of carbamide resin solution increased with increase of crystalline urea addition mass (please see in Table 1). Density is measured with precision $0.001 \mathrm{~g} / \mathrm{cm}^{3}$.

Table 1. Relation between chemical composition of solution and density

\begin{tabular}{|c|c|c|c|c|}
\hline \multicolumn{3}{|c|}{ Chemical composition of resin solution } & \multirow{2}{*}{ Mark } & \multirow{2}{*}{ Density, $\mathrm{g} / \mathrm{cm}^{3}$} \\
\hline Urea-formaldehyde resin, $\mathrm{ml}$ & Water, $\mathrm{ml}$ & Crystalline urea, $\mathrm{g}$ & & \\
\hline 100 & 0 & 0 & - & 1.162 \\
\hline 100 & 50 & 0 & “0” & 1.110 \\
\hline 100 & 50 & 5 & "5" & 1.115 \\
\hline 100 & 50 & 10 & "10" & 1.121 \\
\hline 100 & 50 & 15 & $" 15 "$ & 1.126 \\
\hline 100 & 50 & 20 & "20" & 1.132 \\
\hline 100 & 50 & 25 & $" 25 "$ & 1.137 \\
\hline 100 & 50 & 30 & $" 30 "$ & 1.142 \\
\hline
\end{tabular}

The viscosity of a fluid is a measure of its resistance to gradual deformation by shear stress or tensile stress. Relation between chemical composition of solution and viscosity is given in Table 2. 
Mackevičius, R.; Sližytè, D.; Zhilkina, T.; Turchin, V. 2019. Investigation of influence of additives on properties of multi-molecular organic solutions used for permeation grouting

Table 2. Relation between chemical composition of solution and viscosity

\begin{tabular}{|c|c|c|}
\hline Mark & Time of effusion through capillary of viscosimeter, s & Viscosity, cP \\
\hline “0” & 63.0 & 10.71 \\
\hline "5" & 53.6 & 9.15 \\
\hline "10" & 49.8 & 8.55 \\
\hline "15" & 46.8 & 7.07 \\
\hline "20" & 45.2 & 7.83 \\
\hline "25" & 43.8 & 7.63 \\
\hline "30" & 43.2 & 7.55 \\
\hline
\end{tabular}

Addition of urea decreased viscosity of resin solution. This is positive for flowing permeation of resin solution in voids of sandy soil.

In chemistry, $\mathrm{pH}$ (alkalinity level) is a measure of the acidity or basicity of an aqueous solution. Solutions with a $\mathrm{pH}$ less than 7 are said to be acidic and solutions with a $\mathrm{pH}$ greater than 7 are basic or alkaline. Pure water has a $\mathrm{pH}$ very close to seven.

Laboratory test of urea-formaldehyde resin solutions demonstrate that alkalinity level $\mathrm{pH}$ increased linearly with increase of additive of crystalline urea in the resin solution (see in Figure 1).

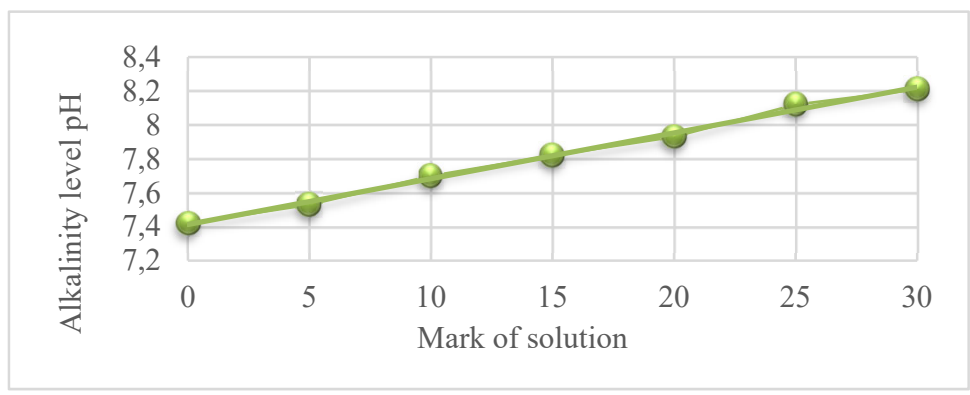

Figure 1. Relation between mark of solution and alkalinity level $\mathrm{pH}$

The amount of free formaldehyde that passes from resin solution into the air in period of 1 year was determined using the authors own method based on the interaction of formaldehyde with a neutral solution of sodium sulfite $\mathrm{Na}_{2} \mathrm{SO}_{3}$ as a result of which a formaldehyde-bisulfite addition compound is formed with the liberation of an equivalent amount of free sodium hydroxide. The latter is titrated with hydrochloric acid, the amount of which is a measure of the content of free formaldehyde in the sample under investigation. Evaporation of free formaldehyde from resin solutions to air is given in Figure 2.

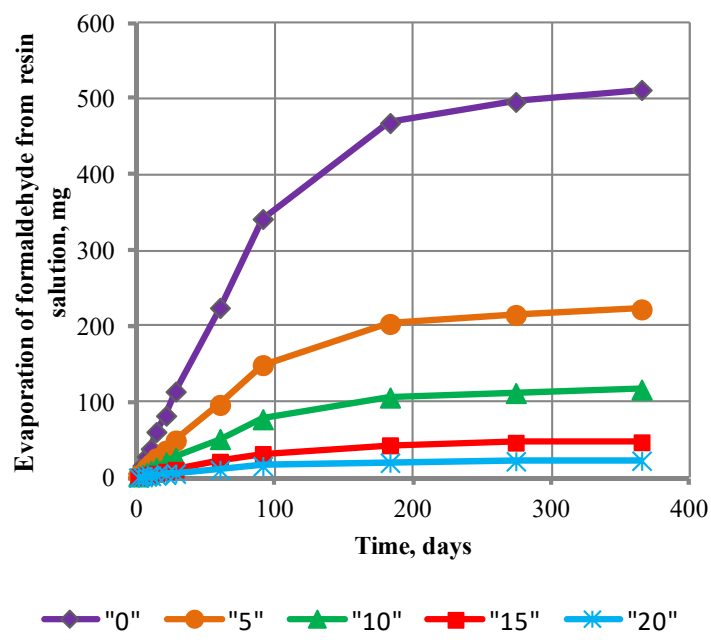

Figure 2. Dependence of free formaldehyde evaporation from resin solutions to air from mark of solution 
The determination of free formaldehyde is made on mixing two neutral solutions, the interaction of which occurring a precisely established time. The reaction takes place more completely at a neutral conditions with $\mathrm{pH}=7$. Under these circumstances, therefore, phenolphthalein was used as a transient indicator.

On addition of the hardener, a resin will begin to become more viscous until it reaches a state when it is no longer a liquid and has lost its ability to flow. This is the gel point. The urea-formaldehyde resin will continue to harden after it has gelled, until, later it has obtained its full hardness and properties.

The gel time of urea-formaldehyde resin solutions with hardener 18 percent ferric chloride $\mathrm{FeCl}_{3}$ solution is given in Figure 3.

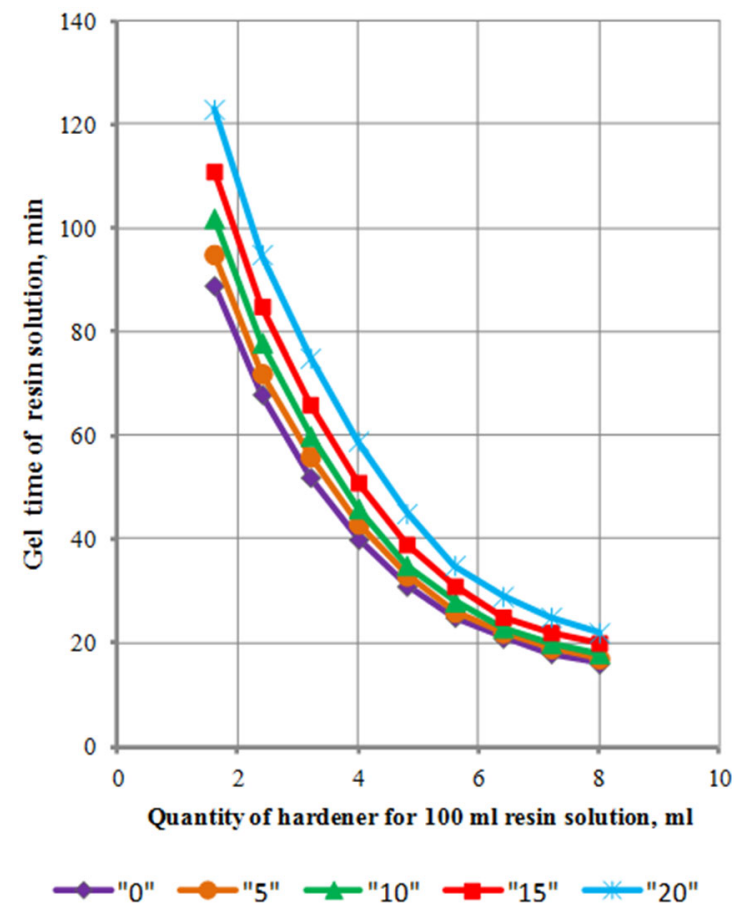

Figure 3. Dependence of gel time of urea formaldehyde resin solution from quantity of hardener $\mathrm{Fe}_{3}$

The laboratory test with investigation of gel time of urea formaldehyde resin give a result: addition of crystalline urea to resin solution increased gel time of this solution. Optimal proportion between hardener solution and resin solution is $1: 25$. In this case, gel time of resin solution is between 40 min for mark " 0 " and 59 min for mark " 20 ". This is enough long gel time for application in soil stabilization techniques.

\section{Conclusions}

1. According laboratory tests, addition of active component (crystalline urea) to urea-formaldehyde resin increase density, $\mathrm{pH}$ (alkalinity level) and gel time of solution, decrease viscosity, and evaporation of free formaldehyde from solution.

2. 10-13 times (composition "15") and 21-25 times (composition "20") less formaldehyde is liberated into the air from soil stabilized with the modified urea-formaldehyde resins than from the soil stabilized with the unmodified resin. The sharp irritating odour of formaldehyde was perceived above the freshly crushed specimens of soil stabilized with the unmodified resin, and acute smarting of the eyes was sensed, while these phenomena were absent in specimens of the soils stabilized with the modified resins. Compositions " 15 " and "20" answer environmental requirements and with hardener ferric chloride according long-time investigations are enough strong for applications in permeation grouting.

\section{References}

Belentsov, Y. A., \& Smirnova, O. M. (2018). Influence of acceptable defects on decrease of reliability level of reinforced concrete structures. International Journal of Mechanical Engineering and Technology, 9(11), 2999-3005.

Bell, F. G. (2013). Methods of treatment of unstable ground. Amsterdam: Elsevier.

Briaud, J. L. (2013). Geotechnical engineering: unsaturated and saturated soils. New Jersey: John Wiley \& Sons. https://doi.org/10.1002/9781118686195

Bruce, D. A. (1994). Overview of grouting developments. Geotechnical News, 12(4), 36-40. 
Cambefort, H. (1964). Injection des sols. Paris: Eyrolles.

Choi, H. G., \& Yanagisawa, E. (1996, May 16-17). Permeation grouting and fracturing in sandy soil. In Proceedings of the $2^{\text {nd }}$ International Conference on Ground Improvement Geosystems (vol. 1, pp. 117-122). Tokyo, Japan.

Gallavresi, F. (1992, February 20-21). Grouting improvement of foundation soils. In Proceedings of the Conference on Grouting, Soil Improvement and Geosynthetics (vol. 1, pp. 1-38). New Orleans, USA.

Granata, R., Vanni, D., \& Mauro, M. (2015). New experience in ground treatment by permeation grouting. Ground Improvement, 168(2), 122-129. https://doi.org/10.1680/grim.13.00026

Henn, R. W. (1996). Practical guide to grouting of underground structures. London: Thomas Telford. https://doi.org/10.1061/9780784411322

Houlsby, A. C. (1990). Construction and design of cement grouting: a guide to grouting in rock foundations. New York: John Wiley \& Sons.

Karol, R. H. (2003). Chemical grouting and soil stabilization (3 ${ }^{\text {rd }}$ ed). New York: Marcel Dekker. https://doi.org/10.1201/9780203911815

Kutzner, Ch. (1996). Grouting of rock and soil. Taylor \& Francis.

Nasu, T. (2000, June 15-16). Development of the super multiple points injection method. In Proceedings of the $4^{\text {th }}$ International Conference on Ground Improvement Geosystems (pp. 273-280). Helsinki, Finland.

Nonveiller, E. (2013). Grouting theory and practice. Amsterdam: Elsevier.

Sokolovich, V. E. (1980). Khimicheskoe zakreplenie gruntov [Chemical stabilization of soils]. Moscow: Stroyizdat (in Russian).

Warner, J. (2004). Practical handbook of grouting: soil, rock, and structures. New Jersey: John Wiley \& Sons.

Welsh, J. P. (1996, May 16-17). State of the art of grouting in North America. In Proceedings of the $2^{\text {nd }}$ International Conference on Ground Improvement Geosystems (vol. 2, pp. 825-831). Tokyo, Japan.

Welsh, J. P., \& Burke, G. K. (2000, November 22-24). Advances in grouting technology. In Proceedings of the International Conference on Geotechnical \& Geological Engineering (vol. 1, pp. 1330-1347). Melbourne, Australia.

Winterkorn, H. F. (1955). The science of soil stabilization. Highway Research Board Bulletin, 108, 1-24. 